APPME is not an organization of social scientists, but of academicians in general, who are mainly not specialists in Middle Eastern affairs. Strictly speaking, there are two organizations: the American Professors for Peace in the Middle East and the American Academic Association for Peace in the Middle East. There are about 15,000 individuals who, in one way or another, are formally or informally connected with our organization and who subscribe to its overall objectives. What APPME is essentially trying to do is to help foster or maintain a climate of opinion percolating through the intellectual world in general, and in the milieu in which decision-making on Middle Eastern issues takes place, in particular. The stated purpose of the association is to utilize the special skills and talents of the academic community to elicit new ideas and approaches for the solution of the ArabIsraeli conflict, and to work for a just and lasting peace in the region. This is more an attempt to clarify issues and suggest policy options rather than pressure-group activity in the classic sense. But it also implies advocacy of certain objectives that we regard as fundamental, of which the continued existence of Israel, not only in security but also in a context of normal relations with its Arab neighbors, is the most significant.

APPME works in a variety of ways: through meetings and lectures on the 600 or so individual campuses at which there are members; academic conferences; briefing sessions; distribution of books, articles and the journal, Middle East Review; and exchanges from time to time with those in the political world who are concerned with similar problems. The last involves meeting members of both the Executive and the Legislature in this country, and also representatives of the different countries in the Middle East. By cogent analysis of issues, APPME has endeavored to persuade policy-makers of the validity of its perceptions of the problems.

APPME believes the scholarship and papers it publishes are taken seriously, both by adherents and by those not sympathetic to its general thrust. Its journal, Middle East Review, is well regarded, and its books now frequently appear in the bibliographies of works by other social scientists. Its works are present in the library of the Middle East Institute in Cairo.

A professor can either join APPME for $\$ 15$ per year and receive the publications it distributes, or those outside academia may make a contribution of $\$ 35$ or more per year to the American Academic Association for Peace in the Middle East (AAAPME) and receive all of its publications. The address is: 9 East 40th St., New York, NY 10016. ....Michael Curtis, Rutgers Univ., AAAPME Chairman ... Fred Gottheil, Univ. of Illinois, APPME Chairman

\title{
Centre for Arab Gulf Studies - University of Exeter
}

The Centre for Arab Gulf Studies of the University of Exeter was formally established, as an independent research institute within the Faculty of Arts, in October 1978. It is the first such centre to be established in the Western world; and is intended to foster research into the society, politics, economics and history of the Arab Gulf region. The area covered by "Arab Gulf" is taken to be the Arabian Peninsula and Iraq; there is a peripheral interest in Iran. The purposes and activities of the Centre include the following:

Documentation: Material so far collected or under collection includes the following: 
- Relevant India Office Archives (microfilm);

- Complete collection of Brussels Information Centre on Eastern Arabia (1969-1979);

- Complete Middle East Economic Digest press cuttings and periodicals (from 1956). Microfiche copies of the former will be available for purchase;

- All possible reports and statistical information produced by ministries, monetary agencies, banks, oil companies, etc.;

- Journals and other publications of Arab Gulf universities and research centres;

- Copies of British and American Ph.D. theses relating to the Arab Gulf;

- Selected Arab Gulf newspapers and periodicals.

Publications: The Centre has an arrangement with Croom Helm for the publication under joint imprint of research works on the Arab Gulf (whether produced within the Centre or commissioned from outside). The Centre will also arrange translation and publication of Arabic language works on the Arab Gulf.

Conferences: Annual three- or four-day international conferences or symposia are being held each summer, focusing on a chosen aspect of Arab Gulf affairs. The 1981 Symposium will be entitled: "Iraq: The Contemporary State."

$$
\begin{gathered}
\text {...Dr. M.A. Shaban, Director, U of Exeter, Exeter, Eng. } \\
\text { Islamic Texts Society }
\end{gathered}
$$

The Islamic Texts Society, a private non-profit association, was formed to provide accurate information on Islam and to make more of its literature available in English translation. The Society is also involved in producing audio-visual materials and in training teachers. For more information, write: Islamic Texts Society, c/o Mrs. A. Gouverneur, Parsonage Farmhouse, Great Sampford, Essex CB10-2RR, England.

\section{Journal of Arab Affairs}

The Journal of Arab Affairs is a journal of informed commentary published twice a year by the Middle East Research Group, Inc. (MERG), a California corporation. The first issue is scheduled for publication in October 1981 .

The articles that will appear in the Journal will not represent any consensus of beliefs and they will not be identified with any one school of thought. The Journal will be hospitable to many divergent and unconventional analyses of Arab affairs. Many of our readers, including members of the Journal's editorial board, will flatly disagree with some opinions and views expressed in some articles. However, we are determined to provide a forum for the unconventional and the daring.

The editor invites contributions on all aspects of contemporary Arab affairs. Address articles to: Editor, Journal of Arab Affairs, 2611 No. Fresno St., Fresno, CA 93703, U.S.A.

\section{Muqamas: An Annual of Ideas and Information on Islamic Art}

Muqarnas, edited by Oleg Grabar, sponsored by the Aga Khan Program for Íslamic Architecture, and published by Yale University Press, is now soliciting articles for its first volume, which is expected to appear in the spring of 1982. Since the new journal's first two volumes will include articles on a variety of subjects and areas, scholars may also contribute to Volume 2 for publication in the year follow- 